\title{
PENGARUH KONSELING KELOMPOK TEKNIK SELF MANAGEMENT TERHADAP POLA HIDUP BERSIH DAN SEHAT SISWA DI KELAS VII SMP NEGERI 1 PERCUT SEI TUAN T.A 2016/2017
}

\author{
Naipa Hanum \\ Asiah, M.Pd \\ Jurusan PPB, Prodi Bimbingan dan Konseling \\ Universitas Negeri Medan
}

\begin{abstract}
Abstrak
Penelitian ini bertujuan untuk mengetahui bagaimana Pengaruh Konseling Kelompok Teknik Self Management Terhadap Pola Hidup Bersih Dan Sehat Siswa di Kelas VII SMP Negeri 1 Percut Sei Tuan T.A 2016/2017. Penelitian ini dilaksanakan pada bulan April s/d Mei 2017. Penelitian ini merupakan penelitian kuantitatif dengan desain eksperimen semu dengan jenis Pre test-post test one group design. Populasi dalam penelitian ini adalah seluruh siswa kelas VII-4. Sampel ditarik dengan menggunakan metode purposive sampling sebanyak 8 orang yang berasal dari kelas VII-4 dengan sampel yang homogen. Data penelitian ini dikumpulkan dengan menggunakan angket pola hidup bersih dan sehat berjumlah 41 item pernyataan yang telah valid dan reliabel kemudian data dianalisis menggunakan uji Wilcoxon. Dari analisis data diperoleh $\mathbf{J}$ hitung $=17$ dengan $\alpha=0,05$, adapun $\mathbf{J}$ tabel $=4$. Dari data tersebut terlihat bahwa $\mathbf{J}_{\text {hitung }}>\mathbf{J}_{\text {Tabel }}$ dimana $17>$ 4. Artinya hipotesis diterima. Data pre-test pola hidup bersih dan sehat diperoleh skor rata-rata 80,1 , sedangkan data post-test penyesuaian diri dengan teman sebaya diperoleh skor rata-rata sebesar 122 . Artinya skor rata-rata siswa setelah mendapat konseling kelompok teknik self management lebih tinggi daripada sebelum mendapat konseling kelompok teknik self management, konseling kelompok teknik self management memberikan kontribusi sebesar 52,30\% terhadap peningkatan pola hidup bersih dan sehat siswa di kelas VII-4 SMP Negeri 1 Percut Sei Tuan.
\end{abstract}

Keywords : Konseling Kelompok, Self Management, Pola Hidup Bersih dan Sehat

PENDAHULUAN

Sekolah selain berfungsi sebagai tempat pembelajaran juga menjadi tempat penularan penyakit jika tidak dikelola dengan baik. Untuk itu sangatlah penting ditanamkan kepada para siswa mengenai pola perilaku hidup bersih dan sehat agar tercipta ketertiban dan kenyamanan pada saat proses pembelajaran berlangsung.

Pola hidup bersih dan sehat adalah semua perilaku kesehatan yang dilakukan atas kesadaran sehingga anggota keluarga atau keluarga dapat menolong dirinya sendiri di bidang kesehatan dan berperan aktif dalam kegiatan-kegiatan kesehatan, karena kesehatan di masyarakat adalah wujud keberdayaan masyarakat yang sadar, mau dan mampu mempraktekkan pola hidup bersih dan sehat (PHBS). Dalam hal ini ada 5 program prioritas yaitu KIA, Gizi, Kesehatan Lingkungan, Gaya Hidup, Dana Sehat / Asuransi Kesehatan/JPKM menurut Depkes (dalam Denti, 2014:28).

Kemudian, dalam hal ini anak pada usia sekolah berada pada kondisi yang sangat peka terhadap stimulus sehingga mudah dibimbing, diarahkan, dan ditanamkan kebiasaan-kebiasaan yang baik, termasuk kebiasaan berperilaku hidup bersih dan sehat. Oleh karena itu, pelaksanaan pola hidup bersih dan sehat 
di sekolah dapat dimulai dari hal yang sederhana seperti mencuci tangan dengan sabun, membuang sampah pada tempatnya, mengkonsumsi jajanan sehat dan bergizi, berolah raga dan lain sebagainya. Maka perilaku ini bermanfaat untuk meningkatkan pencapaian derajat kesehatan, dan siswa menjadi lebih semangat dalam belajar.

Namun pada kenyataannya, beberapa siswa belum menyadari akan pentingnya kebersihan dan kesehatan. Berdasarkan pengamatan peneliti selama melaksanakan program pengalaman lapangan terpadu (PPLT) di SMP N 1 Percut Sei Tuan terdapat beberapa siswa yang belum menerapkan dan menjaga pola hidup bersih dan sehat. Siswa ditemukan membuang sampah sembarangan, tidak menyiram toilet setelah selesai buang air, menempelkan sisa permen karet dibawah meja, hingga membiarkan makanan basi berhari hari didalam laci. Selain itu, masih banyak juga siswa yang kurang menyadari kebersihan diri secara fisik seperti tidak memotong kuku, membiarkan rambut hingga panjang tidak terurus, kaos kaki yang dipakai sampai empat hari berturut turut, dan sebagainya. Dari pernyataan ini dapat dikatakan bahwa siswa tidak sadar akan pentingnya kesehatan, padahal kesehatan dapat mempengaruhi prestasi belajar mereka.

Data yang diproleh dari wawancara terhadap guru BK pada tanggal 12 september 2016 di sekolah SMP N 1 Percut Sei Tuan, dari jumlah siswa kelas VII- 8 yang berjumlah 34 orang 20 diantaranya masih menumpuk sampah didalam lacinya masing masing yang akhirnya menjadi sarang nyamuk dan bisa menyebabkan berbagai penyakit.

Lebih lanjut, Hasil studi pendahuluan yang dilakukan Alby Berri Denti di SMP Negeri 8 Surakarta pada tanggal 14 November 2013 menyatakan bahwa dari jumlah siswa kelas XI, yaitu 106 siswa, 60\% siswa kurang peduli terhadap pola hidup bersih dan sehat, $40 \%$ siswa hanya sekedar mengetahui bagaimana pola hidup bersih dan sehat tanpa menerapkannya secara keseluruhan dalam hidupnya (Denti, 2014: 16).

Berdasarkan data-data di atas, dapat diambil kesimpulan bahwa kebiasan pola hidup yang tidak bersih dan sehat tetap dibiarkan maka akan mengganggu kenyamanan proses belajar sehingga akan berpengaruh terhadap hasil belajar siswa. Oleh karena itu, untuk mengatasi masalah ini perlu diberikan layanan bimbingan konseling. Salah satu cara untuk membantu siswa dalam menerapkan dan menjaga pola hidup 
bersih dan sehat adalah melalui konseling kelompok. Menurut Juntika Nurihsan (dalam Kurnanto, 2013: 7), menyatakan bahwa konseling kelompok adalah suatu bantuan kepada individu dalam situasi kelompok yang bersifat pencegahan dan penyembuhan serta diarahkan pada pemberian kemudahan dalam perkembangan dan pertumbuhannya.

Konseling kelompok merupakan proses konseling yang dilakukan antara seorang konselor profesional dan beberapa klien sekaligus dalam kelompok kecil yang dimanfaatkan untuk meningkatkan pemahaman dan penerimaan diri menuju perilaku yang lebih baik dari sebelumnya.

Teknik yang digunakan oleh peneliti dalam melakukan konseling kelompok ini adalah teknik selfmanagement adalah strategi perubahan tingkah laku atau kebiasaan dengan pengaturan dan pemantauan yang dilakukan oleh klien sendiri dalam bentuk latihan pemantauan diri, pengendalian rangsangan serta pemberian penghargaan pada diri sendiri Komalasari (dalam Isnaini F, 2014:6).

Tujuan self-management dapat mengurangi perilaku yang tidak pantas dan mengganggu (perilaku yang mengganggu, tidak menyelesaikan tugas sekolah dan tugas-tugas secara mandiri dan efisien, dan lain lain) dan meningkatkan sosial, adaptif dan kemampuan bahasa/komunikasi. Neitzel (dalam Isnaini F, 2014: 6)

Dalam melaksanakan strategi pengelolaan diri tahap yang harus dilakukan oleh klien adalah 1) komitmen klien untuk merubah perilakunya, 2) mengidentifikasi perilaku yang diharapkan, 3) penggunaan strategi selfmanagement (self-monitoring, stimulus control dan self-reward), mengevaluasi perubahan perilaku.

Peran layanan konseling kelompok dengan teknik self management disini diperkirakan sangat tepat digunakan sebagai salah satu bentuk yang dapat diberikan kepada siswa untuk dapat menerapkan pola hidup bersih dan sehat. Karena melalui konseling kelompok ini kita dapat mengarahkan siswa melalui pertimbangan, pemikiran, dan keputusannya sendiri.

Mengarahkan siswa agar dapat menerapkan pola hidup bersih dan sehat maka perlu dilakukan kegiatan konseling kelompok teknik self management, dimana dalam teknik ini siswa akan melakukan beberapa langkah menetukan tujuan, memonitor dan mengevaluasi tujuan, dan memberikan penguatan diri. Sejalan dengan hal ini maka peneliti ingin mengadakan penelitian dengan 
mengangkat judul: "Pengaruh Konseling Kelompok Teknik Self Manangement Terhadap Pola Hidup Bersih Dan Sehat Siswa Di Kelas VII SMP Negeri 1 Percut Sei Tuan T.A 2016/2017".

\section{KAJIAN PUSTAKA}

\section{Konseling Kelompok}

Juntika Nurihsan (dalam Kurnanto, 2013: 7) mengatakan konseling kelompok merupakan suatu bantuan kepada individu dalam situasi kelompok yang bersifat pencegahan dan penyembuhan serta diarahkan pada pemberian kemudahan dalam perkembangan dan pertumbuhannya. Selanjutnya Gazda (dalam Astuti, 2015: 4) mengatakan konseling kelompok adalah suatu proses antara pribadi yang dinamis, yang terpusat pada pemikiran dan perilaku yang disadari. Proses itu mengandung ciri-ciri terapeutik seperti pengungkapan pikiran dan perasaan secara leluasa, orientasi pada kenyataan, keterbukaan diri mengenai seluruh perasaan mendalam yang dialami, saling percaya, saling perhatian, saling pengertian dan saling mendukung. Semua ciri terapeutik tersebut diciptakan dan dibina dalam sebuah kelompok kecil dengan cara mengemukakan kesulitan dan empati pribadi kepada sesama anggota kelompok dan kepada konselor. Para konseli adalah orang-orang yang pada dasarnya tergolong orang normal, yang menghadapi berbagai masalah yang tidak memerlukan perubahan secara klinis dalam struktur kepribadian untuk mengatasinya. Para konseli dapat memanfaatkan suasana komunikasi antarpribadi dalam kelompok untuk meningkatkan pemahaman dan penerimaan terhadap nilai nilai kehidupan dan segala tujuan hidup, serta untuk belajar dan atau menghilangkan suatu sikap dan perilaku tertentu.

Berdasarkan pendapat di atas dapat ditarik kesimpulan bahwa konseling kelompok adalah proses bantuan yang berikan oleh tenaga ahli atau konselor kepada individu dalam situasi kelompok yang mengandung ciri-ciri terapeutik seperti pengungkapan pikiran dan perasaan secara leluasa, orientasi pada kenyataan, keterbukaan diri mengenai seluruh perasaan mendalam yang dialami, saling percaya, saling perhatian dan pengertian serta saling mendukung untuk menyelesaikan permasalahan yang dialami seperti masalah pribadi, sosial, karir dan belajar.

Kurnanto (2013: 9) menyatakan bahwa konseling kelompok memiliki 2 fungsi yaitu fungsi preventif dan kuratif. Fungsi preventif merupakan layanan konseling yang diarahkan untuk mencegah terjadinya persoalan pada diri 
individu sedangkan fungsi kuratif merupakan layanan yang diarahkan untuk mengatasi persoalan yang dialami individu. Sejalan dengan pendapat Juntika Nurihsan 2006 (dalam Kurnanto, 2013: 9) mengatakan bahwa konseling kelompok memiliki fungsi pencegahan dan penyembuhan.

Dikatakan oleh Jacob, at al. (dalam Kurnanto, 2013: 10) bahwa ketika seorang pemimpin kelompok belum jelas tentang tujuan kelompok yang dipimpinnya, maka kecenderungan kelompok tersebut akan sering membingungkan, membosankan atau tidak produktif atau pemimpin tidak mengikuti tujuan yang dinyatakan. Selain itu, tujuan kelompok dapat berubah sebagaimana perkembangan yang terjadi pada kelompok. Jika konselor menguasai proses klarifikasi tujuan, berikutnya yang penting dari aspek kepemimpinan kelompok yang efektif adalah perencanaan.

\section{Self Management (Manajemen Diri)}

Teknik self management merupakan bagian dari pendekatan behavioristik. Menurut J.B. Watson (dalam Desyani R., 2014: 25), pendekatan behavioristik merupakan salah satu teori psikologi yang fokus materi kajiannya hanyalah prilaku nyata (over behavior), tidak terkait dengan hubungan kesadaran atau kontruksi mental lainnya. Selain itu juga merupakan cabang ilmu pengtahuan alam yang secara penuh bersifat exprimental dan objektif dengan tujuan untuk meramalkan dan mengontrol prilaku.

Hamza B Uno (2008: 219) mengatakan bahwa self management atau manajemen diri adalah prilaku siswa yang bertanggung jawab terhadap pengaturan segala prilakunya sendiri, dengan tujuan agar siswa bisa lebih mandiri, lebih independen, dan lebih mampu memprediksi masa depannya sendiri.

Sementara menurut Komalasari (dalam Jurnal Pencerahan, Vol. X No. 2 September 2016) mengatakan pengubahan perilaku maupun kebiasaan konseli dengan cara mengatur dan memantau, yang dilakukan oleh konseli dalam bentuk latihan pemantauan diri, pengendalian rangsangan, serta pemberian penghargaan pada diri sendiri tanpa paksaan orang lain.

Menurut Gie (dalam Supriyati, 2013: 12) Self management berarti mendorong diri sendiri untuk maju, mengatur semua unsur kemampuan pribadi, mengendalikan kemampuan untuk hal hal yang baik, dan 
mengembangkan berbagai segi kehidupan agar lebih sempurna.

Dari beberapa pendapat di atas, dapat disimpulkan bahwa self management adalah suatu bentuk prilaku maupun kebiasaan seseorang dalam mengatur, memantau, mengarahkan maupun mengendalikan diri sendiri untuk menyelesaikan permasalahan atau mencapai tujuan tertentu demi kehidupan yang lebih baik.

\section{Tahap-Tahap Teknik Self Management}

Menurut Hamza B Uno (2008: 211217) ada beberapa prosedur dalam melakukan self management yaitu: 1) Tahap Memonitor diri dan Observasi Diri. Pada tahap ini konselor mengarahkan konseli mengamati tingkah lakunya sendiri dan mencatatnya dengan teliti. Konselor membuat program yang memungkinkan pencapaian tujuan tertentu, seperti menggunakan daftar cek atau catatan observasi kualitatif yang akan dikerjakan konseli nantinya dengan cara misalnya mencatat perilaku-perilaku yang ingin diubah, perilaku-perilaku yang ingin ditingkatkan.Sebagaimana Adler (dalam Hamza B Uno, 2008: 213) menyatakan bahwa prilaku seseorang diarahkan pada tujuan masa mendatang yang sudah disusun sendiri. Ide seseorang lebih ditentukan oleh harapannya dimasa mendatang dari pada pengalamannya di masa lampau; 2) Mencatat Dan Mengevaluasi Kemajuan. Pada tahap ini konselor mengarahkan konseli untuk membandingkan hasil catatan tingkah laku yang telah dibuat oleh konseli atau mengkombinasikan penetapan tujuan, pencatatan diri dan evaluasi diri. Perbandingan ini bertujuan untuk mengevaluasi efektivitas dan efisiensi program yang telah dibuat. Bila program tersebut tidak berhasil, maka program tersebut perlu ditinjau kembali, apakah target tingkah laku yang ditetapkan memiliki ekspestasi yang terlalu tinggi, tidak cocok, atau penguatan yang diberikan tidak sesuai; 3) Penguatan Diri (Self Reinforcement). Tahap terakhir dalam teknik self managemen adalah penguatan diri (self reinforcement). Penguatan diri terjadi saat konseli memberikan hadiah kepada dirinya sendiri karena sukses mencapai prestasi atau kinerja yang sudah ditetapkan atau saat seseorang menghukum dirinya sendiri karena sudah gagal mencapai kinerja atau prestasi yang ditetapkan. Oleh karena itu, bagi konselor tahap ini merupakan tahap yang sulit karena konseli harus ada kemauan yang kuat untuk melaksanakan program yang telah dibuat secara kontiniu, yaitu mengatur dirinya sendiri, memberikan penguatan, menghapus, dan memberikan hukuman 
pada diri konseli ketika konseli berhasil atau gagal menjalankan program yang telah dibuat.

\section{Pola Hidup Bersih Dan Sehat}

Pola hidup bersih dan sehat adalah semua perilaku kesehatan yang dilakukan atas kesadaran sehingga anggota keluarga atau keluarga dapat menolong dirinya sendiri di bidang kesehatan dan berperan aktif dalam kegiatan-kegiatan kesehatan di masyarakat Adalah wujud keberdayaan masyarakat yang sadar, mau dan mampu mempraktekkan Pola Hidup Bersih Dan Sehat. Dalam hal ini ada 5 program priontas yaitu KIA, Gizi, Kesehatan Lingkungan, Gaya Hidup, Dana Sehat/Asuransi Kesehatan/JPKM menurut Depkes (dalam Denti, 2014: 28). Setiowati, S (2012:12) menyatakan bahwa : Pola Hidup Bersih dan Sehat (PHBS) merupakan sekumpulan perilaku dibidang kesehatan yang dipraktikan atas dasar kesadaran sebagai hasil pembelajaran yang menjadikan seseorang atau keluarga dapat menolong dirinya sendiri dibidang kesehatan dan berperan aktif dalam mewujudkan kesehatan di masyarakatnya.

Pola Hidup Bersih dan Sehat adalah upaya untuk memberikan pengalaman belajar atau menciptakan suatu kondisi bagi perorangan, keluarga, kelompok dan masyarakat, dengan membuka jalur komunikasi, memberikan informasi dan melakukan edukasi untuk meningkatkan pengetahuan, sikap dan perilaku melalui pendekatan pimpinan (advocacy), bina suasana (social support) dan pemberdayaan masyarakat (enpowerment) sebagai suatu upaya untuk membantu masyarakat mengenali dan mengetahui masalah sendiri, dalam tatanan rumah tangga, agar dapat menerapkan cara cara hidup sehat dalam rangka menjaga, memelihara dan meningkatkan kesehatan. (Notoadmojo, dalam Denti 2014:28).

Dari beberapa pengertian diatas dapat ditarik kesimpulan bahwa pengertian dari pola hidup bersih dan sehat adalah perilaku yang dilakukaan secara sadar sebagai upaya untuk mengenali, menerapkan, memelihara, dan meningkatkan cara hidup yang bersih agar hidup menjadi sehat sehingga memiliki kemampuan dan nyaman untuk melakukan tugas maupun kegiatan sehari hari.

Tujuan pola hidup bersih dan sehat adalah untuk meningkatkan pengetahuan, kesadaran, kemauan dan kemampuan masyarakat agar hidup bersih dan sehat, serta meningkatkan peran serta aktif masyarakat termasuk swasta dan dunia usaha, dalam upaya mewujudkan derajat 
kesehatan yang optimal. (Proverawati dalam Denti, 2014:14).

Pola hidup bersih dan sehat disekolah adalah upaya untuk memberdayakan siswa, guru, dan masyarakat lingkungan sekolah agara tahu, mau dan mampu mempraktekkan pola hidup bersih dan sehat, dan berperan aktif dalam mewujudkan sekolah sehat. Sekolah adalah lembaga dengan organisasi yang tersusun rapi dengan segala aktivitasnya direncanakan dengan sengaja disusun yang disebut kurikulum Ahmadi (dalam Sulastri, 2014: 99).

Pola hidup bersih dan sehat di institusi pendidikan adalah upaya pemberdayaan dan peningkatan kemampuan untuk berperilaku hidup bersih dan sehat di tatanan institusi pendidikan. Indikator pola hidup bersih dan sehat di institusi pendidikan/ sekolah meliputi Depkes (dalam Denti, 2014: 2934) yaitu :

1) Mencuci tangan dengan air yang mengalir dan memakai sabun

2) Mengkonsumsi jajanan sehat di kantin sekolah

3) Menggunakan jamban yang bersih dan sehat

4) Olahraga yang teratur dan terukur

5) Memberantas jentik nyamuk

6) Kebersihan dan kesehatan anggota badan
7) Menimbang berat badan dan mengukur tinggi badan setiap bulan

8) Membuang sampah pada tempatnya

\section{METODE PENELITIAN}

Sesuai dengan pembahasan dan metode penelitian, pendekatan yang digunakan adalah pendekatan kuantitatif dengan eksperimen semu jenis pretest posttest one group design sehingga data diperoleh dari perbandingan angket sebelum dilaksanakan kegiatan konseling kelompok teknik self management dengan angket sesudah dilaksanakan kegiatan konseling kelompok teknik self management.

Penelitian ini diberikan kepada 8 orang siswa kelas VII-4 SMP Negeri 1 Percut Sei Tuan sebagai sampel penelitian. Pemilihan sampel ini dilakukan dengan purposive sampling dimana peneliti memilih sampel yang homogen yang terdiri dari 5 orang siswa dengan kategori pola hidup bersih dan sehat yang rendah, dan 3 orang siswa dengan kategori kategori pola hidup bersih dan sehat yang sedang. Diantara 8 orang tersebut ada 2 orang siswa perempuan dan 6 orang siswa laki-laki. Dengan pengelompokan seperti ini diharakan penerapan pola hidup bersih dan sehat siswa semakin baik sehingga tujuan dari konseling kelompok teknik self management dapat tercapai. 


\section{HASIL DAN PEMBAHASAN}

Adapun hasil pre-test sebelum diberi layanan konseling kelompok teknik Self management dengan $\mathrm{n}=8$ maka diperoleh jumlah nilai sebesar 641, ratarata $=80,1$, standar deviasi $=15,84$, skor maksimal $=101$, skor minimal $=65$.

Setelah diberikan layanan konseling kelompok teknik self management, maka diperoleh hasil penelitian dengan jumlah responden 8 orang yaitu responden dengan 7 kategori tinggi dan 1 kategori sangat tinggi

Berdasarkan data post-test yang diperoleh dari hasil penelitian dengan jumlah responden 8 orang, maka diperoleh jumlah nilai sebesar 979, ratarata $=122$, standar deviasi $=8,27$ skor maksimal $=138$, skor minimal $=111$.

Jadi dapat disimpulkan bahwa ada peningkatan penerapan pola hidup bersih dan sehat dari yang rendah menjadi tinggi setelah diberikan layanan konseling kelompok teknik self management dengan perubahan interval sebesar $52,30 \%$.

Hasil perbandingan Pre-test dan Post-test dapat dilihat pada tabel dibawah ini :

Tabel. 1 Data Hasil Angket Pre-Test dan Angket Post-Test

\begin{tabular}{|c|c|c|c|}
\hline Responden & $\begin{array}{c}\text { Skor } \\
\text { Pre- } \\
\text { Test }\end{array}$ & $\begin{array}{c}\text { Skor } \\
\text { Post- } \\
\text { Test }\end{array}$ & Beda \\
\hline FE & 101 & 138 & 37 \\
\hline HP & 99 & 127 & 28 \\
\hline
\end{tabular}

\begin{tabular}{|c|c|c|c|}
\hline HR & 97 & 114 & 17 \\
\hline NR & 72 & 124 & 52 \\
\hline SP & 72 & 124 & 52 \\
\hline SS & 68 & 120 & 52 \\
\hline VA & 67 & 121 & 54 \\
\hline YS & 65 & 111 & 46 \\
\hline Jumlah & 641 & 979 & \\
\hline $\begin{array}{c}\text { Nilai } \\
\text { Tertinggi }\end{array}$ & 101 & 138 & \\
\hline $\begin{array}{c}\text { Nilai } \\
\text { Terendah }\end{array}$ & 65 & 111 & \\
\hline Rata-rata & 80,1 & 122 & \\
\hline \multicolumn{2}{|c|}{ Pada perteman } \\
\hline
\end{tabular}

Pada pertemuan pertama, peneliti melaksanakan bimbingan kelompok dan memberikan informasi umum tentang pola hidup bersih dan sehat yang harus diterapkan oleh siswa, dan bagai mana dampaknya terhadap kesuksesan proses belajar mengajar. Proses ini berfungsi untuk menakrabkan anggota kelompok yang satu dengan yang lainnya.

Kemudian pada pertemuan kedua dilaksanakan konseling kelompok dengan tema mencuci tangan dengan baik dan benar.

Pada pertemuan ketiga, membahas tentang jarak menggunakan jamban dengan bersih dan sehat. Pada pertemuan keempat, tema yang dibahas adalah kebersihan dan kesehatan anggota badan/ tubuh. Pemimpin dan anggota kelompok saling berdiskusi bagaimana agar nantinya permasalahan mengenai kebersihan dan kesehatan anggota badan/ tubuh ini dapat diminimalisir sehingga tidak mengganggu proses belajar dikelas.

Pada pertemuan kelima, tema yang dibahas adalah kebersihan lingkungan 
yang memegang peranan penting disekolah agar siswa lebih nyaman, fokus dan konsentrasi saat belajar.tidak hanya siswa yang wajib menjaga kebersihan akan tetapi guru juga berperan untuk mengerah kan dan memantau begitu juga staf lainnya.

Dengan konseling kelompok teknik self management siswa menjadi mampu membedakan perilaku yang seharusnya dilakukan dan prilaku yang tidak seharusnya dilakukan mengenai penerapan pola hidup bersih dan sehat dengan membuat perbandingan antara observasi diri dan target prilaku. Konseling kelompok memiliki peranan penting dalam membantu mengatasi masalah pola hidup bersih dan sehat yang merupakan masalah pribadi dan juga masalah sosial. Hal itu sesuai dengan tujuan self-management yaitu dapat mengurangi perilaku yang tidak pantas dan mengganggu (perilaku yang mengganggu, tidak menyelesaikan tugas sekolah dan tugas-tugas secara mandiri dan efisien, dan lain lain) Neitzel (dalam Isnaini F, 2014: 6). Setelah melaksanakan kegiatan konseling kelompok siswa lebih mengurangi kebiasaan jorok dalam kelas yang membuat proses belajar kurang nyaman. Para siswa menjadi peduli terhadap kebersihan dan kesehatan tubuh serta lingkungannya sehingga proses belajar pun berjalan dengan lebih baik, fokus dan konsentrasi pada pelajaran yang mereka ikuti .

Dengan demikian, gambaran penerapan pola hidup bersih dan sehat setelah melaksanakan konseling kelompok mengalami peningkatan. Tidak ditemukan mahasiswa yang masih memiliki pola hidup bersih dan sehat pada kategori rendah, Terlihat bahwa semua anggota kelompok menunjukkan peningkatan yang signifikan yaitu dari kategori rendah dan sedang menjadi kategori tinggi.

Hasil analisa data yang diperoleh dalam penelitian ini adalah nilai $\mathrm{J}$ hitung $=17$ dengan $\alpha=0,05$ dan $n=8$. Maka berdasarkan daftar, $\mathrm{J}$ tabel $=4$. Dari data tersebut terlihat bahwa $\mathbf{J}_{\text {hitung }}>\mathbf{J}_{\text {Tabel }}$ dimana $17>4$. Artinya hipotesis diterima. Data pre-test diperoleh rata-rata 80,1 , sedangkan data post-test setelah diberikan layanan konseling kelompok teknik self management diproleh rata-rata sebesar 122. Artinya skor rata-rata siswa setelah mendapat layanan konseling kelompok teknik self management lebih tinggi daripada sebelum mendapat layanan konseling kelompok teknik self management. Perubahan peningkatan interval pola hidup bersih dan sehat siswa dikelas setelah diberi layanan konseling 
kelompok teknik self management sebesar $52,30 \%$.

\section{PENUTUP}

\section{Simpulan}

Berdasarkan hasil penelitian yang telah dilaksanakan oleh peneliti, maka diperoleh kesimpulan bahwa ada pengaruh layanan konseling kelompok pendekatan self management terhadap pola hidup bersih dan sehat siwa dikelas SMP N 1 Percut Sei Tuan T.A 2016/2017.

Setelah melaksanakan kegiatan konseling kelompok siswa lebih mengurangi kebiasaan jorok dalam kelas yang membuat proses belajar kurang nyaman. Para siswa menjadi peduli terhadap kebersihan dan kesehatan tubuh serta lingkungannya sehingga proses belajar pun berjalan dengan lebih baik, fokus dan konsentrasi pada pelajaran yang mereka ikuti .

Hasil analisa data yang diperoleh dalam penelitian ini adalah nilai hitung $=17$ dengan $\alpha=0,05$ dan $n=8$. Maka berdasarkan daftar, $\mathrm{J}$ tabel $=4$. Dari data tersebut terlihat bahwa $\mathbf{J}_{\text {hitung }}>\mathbf{J}_{\text {Tabel }}$ dimana $17>4$. Artinya hipotesis diterima. Data pre-test diperoleh rata-rata 80,1, sedangkan data post-test setelah diberikan layanan konseling kelompok teknik self management diproleh rata-rata sebesar 122. Artinya skor rata-rata siswa setelah mendapat layanan konseling kelompok teknik self management lebih tinggi daripada sebelum mendapat layanan konseling kelompok teknik self management. Perubahan peningkatan interval pola hidup bersih dan sehat siswa dikelas setelah diberri layanan konseling kelompok teknik self management sebesar 50,30\%. Hal ini menunjukkan bahwa hipotesis dapat diterima.

\section{Saran}

Adapun saran yang dapat dikemukakan peneliti adalah agar Kepala Sekolah lebih memberikan fasilitas, sarana dan prasarana kegiatan layanan bimbingan dan konseling di sekolah agar tujuan yang diharapkan dapat tercapai secara optimal. Guru Pembimbing diharapkan menindaklanjuti kegiatan layanan bimbingan kelompok dengan mengadakan kegiatan konseling kelompok untuk penyelesaian yang lebih lanjut. Bagi siswa/i yang masih memiliki pola hidup bersih dan sehat rendah seharusnya lebih bergiat untuk menunjukkan kemampuan positif apa saja yang dimilikinya dan mengikuti layanan bimbingan konseling yang diadakan guru pembimbingnya. Diharapkan bagi peneliti lain dapat dijadikan sebagai bahan masukan dan sumber referensi dalam penelitian di bidang yang sama terutama untuk menumbuhkembangkan 
kemampuan dan keterampilan meneliti serta menulis

\section{DAFTAR PUSTAKA}

Astuti, Dwi Rochayatun. 2015. Teknik Modeling Dalam Bimbingan Kelompok Untuk Meningkatkan Kemandirian Belajar Siswa. Skripsi FDK UIN Sunan Kalijaga Yogyakarta: Tidak Diterbitkan.

Denti, A. 2014. Tingkat Pengetahuan Remaja Tentang Prilaku Hidup Bersih Dan Sehat PHBS Pada Pelajar Kelas XI SMA Negeri 8 Surakarta Tahun 2014. Karya Tulis Ilmiah Diploma III STIKes Kusuma Husada Surakarta.

Desyani, Rahma. 2014. Telaah Unsur Unsur Behavioristik Pada Pendekatan Dan Metode Behavioristik. Skripsi Fakultas Tarbiah UIN Sunan Kalijaga Yogyakarta.

Isnaini, F. 2014. Strategi Self Management Untuk Meningkatkan Kedisiplinan Belajar. Skripsi Sains Psikologi Universitas Muhammadiyah Surakarta.

Kurnanto, Edi. 2013. Konseling Kelompok. Bandung: Alfabeta.
Setowati, S Dan Kurniadi, A. 2012. Penerapan Pola Hidup Bersih Dan Sehat (PHBS) Dengan Media Pembelajaran Bentuk Video Game Bagi Anak Anak Taman Kanak Kanak. Laporan Penelitian, FK Universitas Dian Nusantoro.

Sulastri, Ketut. Dkk. 2014. Hubungan Tingkat Pengetahuan Dengan Prilaku Anak Sekolah Tentang Hidup Bersih Dan Sehat. Di SD N Wilayah Puskesmas Selemadeg Timur II. Journal kesehatan lingkungan vol. IV no. 1 hal 99106.

Supriyati, Anik. 2013. Upaya Meningkatkan Self Management Dalam Belajar Melalui Layanan Bimbingan Kelompok Pada Siswa Kelas VIII D Di SMP N 1 Jakenan Pati. Skripsi FIP UNNES.

Uno, Hamza B .2008. Orientasi Baru Dalam Psikologi Pembelajaran. Jakarta: Bumi Aksara.

Wibowo, Mungin Eddy. 2005. Konseling Kelompok Perkembangan. Semarang: Unnes Press 